\title{
MAJAPAHIT TERRACOTTA FIGURINES: SOCIAL ENVIRONMENT AND LIFE
}

\author{
Dikdik Adikara Rachman \\ Department of Visual Communications, Universitas Trisakti \\ Jln. Kyai Tapa No. 1, Grogol, Jakarta 11440 \\ Adikara.rachman@sacredbridge.org
}

\begin{abstract}
This article aimed to determine the three-dimensional visual tradition in the Majapahit kingdom. This was a manifestation of aesthetic that expressed in various forms, one of them was the figurines that represented linkage aspects in Majapahit's community life. Terracotta was used as the main basic material in making figurines. Figurines indicated two aspects, namely the human relationship with the natural environment surrounding that translated into a mechanism for the creation, and showed the dimensions of social life in the Hindu tradition. The method used is empirical relational visual with text. In addition, the article was the result of field research conducted under the supervision of Sacred Bridge Foundation, which lasted from 2009 to 2010 in Trowulan as a heritage center site of Majapahit that spread over an area of nearly $100 \mathrm{~km} 2$. The research finds out that figurines as a proof of authenticity and identity of the Majapahit that understood as the embodiment of visual culture manifestation.
\end{abstract}

Keywords: figurine, Majapahit, environment and social life, Hinduism, visual culture

\section{INTRODUCTION}

The Majapahit Kingdom was known as the biggest Hindu Kingdom at Nusantara (the area now generally known as Indonesia) that held power from 1293 until its collapse on 1518 (Hefner, 1983). Almost all writings about history of the Kings at Java, including Majapahit, emphasizing the political dimension of power than others, which revealed the struggle for power and conquest rights of other regions in the form of war. The political dimension has dominated other values. One of the values of Majapahit society was the richness of visual culture as part of their tradition, which based on agriculture. Tanudirdjo (1993) explained that Majapahit relied on agriculture because people were able to develop irrigation technology.

Visual proof that they were the agriculture society could be identified through heritage site of irrigation technology in the form of a number of pipes for the water circulation and distribution that were made from baked clay (terracotta) and Segaran (pond). The main proof was Trowulan geography, as alluded by Sutikno (1993), which said that the area Trowulan (Majapahit) was located between the mountains of tropical rain climate. Then based on land geomorphology, Majapahit was relatively fertile and flat. These facts also had been written on the inscription Kudadu at 1294. Geomorphologic transcription had been found on some pieces of reliefs that showed people were farming and plowing. Based on that, there was another aesthetics manifestation about Majapahit. It tells us that Majapahit was not solely about power.

Geologically, the natural environment of Majapahit consists of old quarter volcanic sediment, which contains of sand, gravel, clay soil, and abundant loam (Nuryadi, 2009). The content of loam known as basic material of terracotta, which later became the basic material for a wide variety of 
functional purposes including artwork. Kusen, Triharyantoro, \& Haryono (1993) stated, "Majapahit artwork gave the sense that art in various forms of expression had been grown and developed in Majapahit”. Judging from its nature, Majapahit arts can be grouped into artifact and non-artifact. Figurines includes into artifact art.

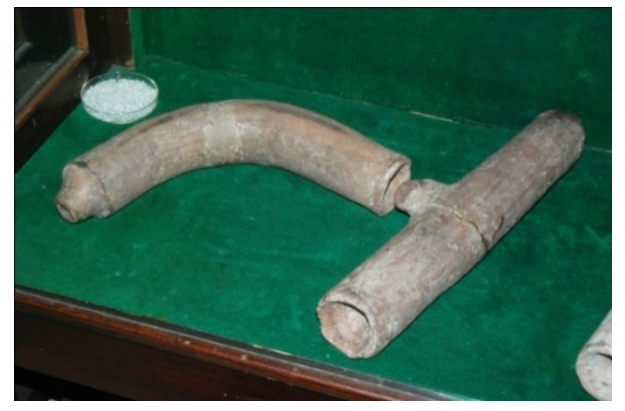

Figure 1 Majapahit Artifacts, Terracota Pipe (Doc: Rachman, 2010)

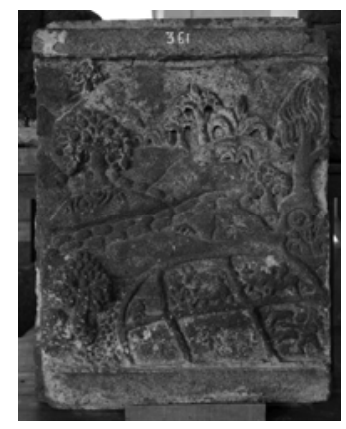

Figure 2 Relief of Plowing (Doc: Rachman, 2010)

\section{METHODS}

Research methodology of this paper is relational of visual empiric and text. Term of relational of visual empiric is regarding to figurine and the meaning of its interpreting of terracotta human figure gestures in minor scale. Text means as well as explanations in writing about figurines includes inscription that translated into Bahasa. During research, date of figurines establishment had not been found yet. The figurine was a visual culture tradition during Majapahit under Hayam Wuruk, that hold the stable power at 1350 - 1389. It had been written on inscription Kakawin Negarakertagama (Pigeaud, 1962).

This paper is a result of research that conducted under supervision of Sacred Bridge Foundation (SBF) held in between 2009 and 2010 at Trowulan. Trowulan as a heritage site center of Majapahit that spread over an area of nearly $100 \mathrm{~km} 2$. Background of this research is a pre-colonial visual culture that has local authenticity which was built during the $12^{\text {th }}$ century up to the $15^{\text {th }}$ century, at least in Java. During this long period, there were so many writings about Majapahit, but it is so rare discussion about the richness of visual culture academically. The writer assumption is politics and economics stability give certain insurance towards the development and the establishment of works arts maximally.

\section{RESULTS AND DISCUSSIONS}

Clay (terracotta) was the main material for various purposes and massively used by the Majapahit people. Beside Clay used to make goods for daily needs, almost the whole sites were built using it, for example Kedaton (the biggest one). Kedaton has different layer structures that all of the layers were made with bricks. Segaran, Brahu temple, BajangRatu temple, miniatures and piece of architecture pillar, road, various containers and tools, figurine, even technology for circulating and distributing water also used clay as material. It makes clay became central, not only in level of conception of art and design, but also in level of its realization. 


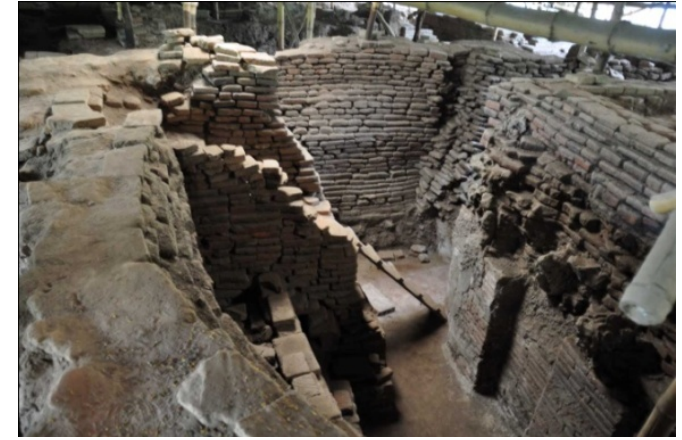

Figure 3 Kedaton Site Structure (Doc: Rachman, 2010)

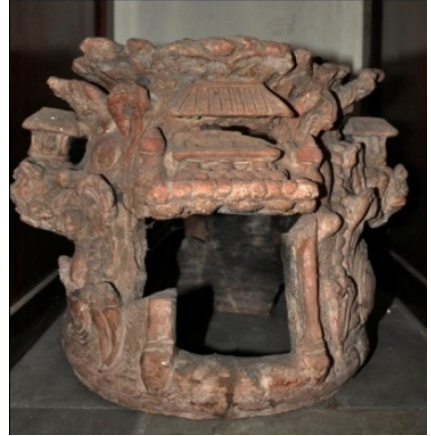

Figure 4 Terracotta Stove (Doc: Rachman, 2010)

Figurines as part of self-created art have peculiarities. It has small size with 8 to 12 centimeters height, accentuate someone's character and perception. All of them reflect how the daily life takes place and controlled by Hinduism. Figurines can generally be said to be small-sized statues, as expressed by Soemantri (1997), "Commonly the figurines are small, measuring, and constructed by the coil and pinch methods with carved or incised decorations, a forming method that is sculptural”.

Figurine shapes and characters are grouped into two large groups, they are the complete figurines and the head. Both of them show the ability of the sculptor in capturing the human's role and profession and power of expression that is aligned with Hinduism teachings. The art quality that are shown by every figurine is different, ranging from detailed to simple one. In general, figurines represent individual in generations and social strata, and the presence of foreigners (Portuguese, Chinese, Arab/Indian). The differences between figurines become a visual attraction that displayed through the shapes, characters, and the ornamental approach.

The sculptor in the Majapahit era has obtained careful identification abilities and adequate skill. Based on the different quality of shapes and characters, it can be said that Majapahit people had a trend in making figurines and the simple figurines was the result of a learning mechanism by a group of people who taught by the expert (maestro) at that time. These two possibilities can be adequately accepted if connected by the growth of collective consciousness towards identity, and it was supported by the abundance of natural resources. At the same time, they had successfully developed a burning technique using wood and leftovers from farming harvests, such as corn stalks and rice stalks. And they used sekam as heating source. The fact that they used harvest leftovers can be traced to the tradition of planting corn and rice, which had long been developed in Java to fulfill their needs for food sustenance (Yulianto, 1986).

In general, figurines of complete body shapes are plastic, but in some cases, there are shapes that are anatomically not ideal. Even so, they attempt to portray the whole complete body with all its parts as demanded by doctrines and norms. Norm as one manifestation of wide vision of laws and rules about daily morality in the Hindu (Olivelle, 2005). This imperfect of figurines are most possibly caused by the demands of a large number of productions, which results in the portrayal of the figurines' complete bodies must be put behind. The detail in this case refers to muscular volume, facial expression, and the ornamentals attached to figurines itself.

The plastic shape is resulted from the character of clay that easy to handle. This can be seen from several figurines in a sitting position whose sizes are not the same. They produced these figurines by making them manually one by one without using mold, while the molding technique had already been developed in making of floor tiles and brick walls. Production unit of per individual figurine 
signifies its exclusiveness, which also shows the level of expertise of sculptor. The pictures below are examples of complete and detailed figurines:

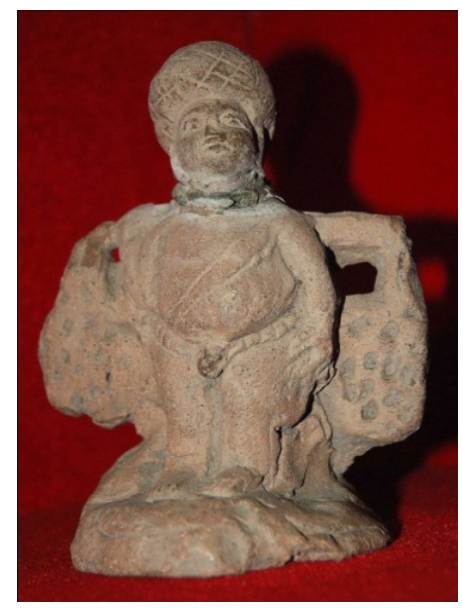

Figure 5 A Priest in Ritual Dress

(Doc: Rachman, 2010)

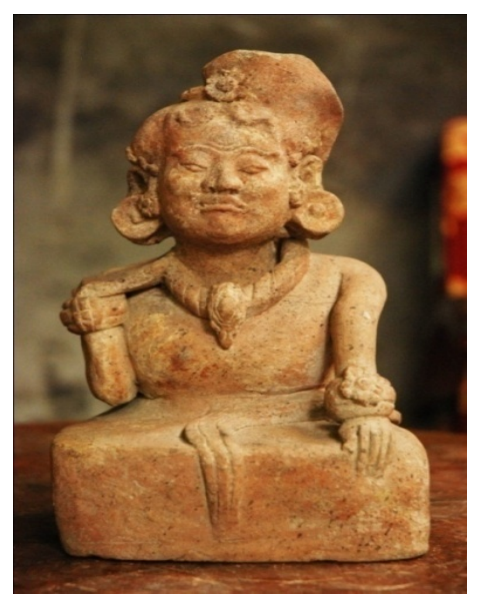

Figure 6 Female Court Attendee (Doc: Rachman, 2010)

The pictures above show a gender difference. Figure 5 is male, it can be seen from the body shape. Meanwhile Figure 6 is female, it can be seen by the shape of the headdress, bracelet, necklace, and other details although the body type has elements of masculinity. Other figurines that is found is incomplete figurines. The number of incomplete figurines is much bigger than complete figurines. It because of the long period of time causes these figurines had possibly experience physical pressure because they were buried under earth, damage due to less-careful excavation, and the weak molecular structure of clay. The figurines get great attention by the Majapahit Information Center or Pusat Informasi Majapahit (PIM) like the other artifacts. The pictures below are the examples of incomplete figurines:

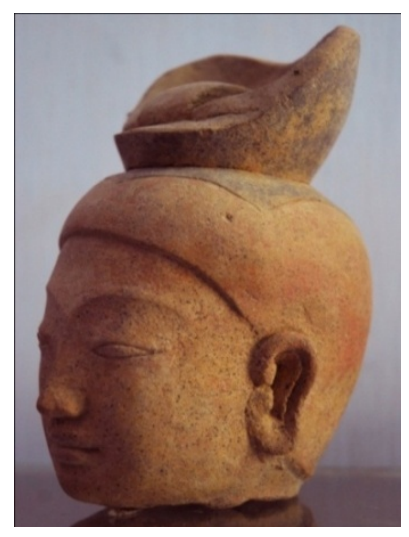

Figure 7 Head of Chinese (Doc: Rachman, 2010)

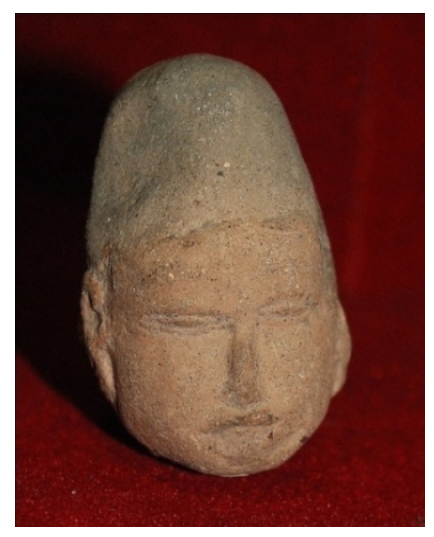

Figure 8 Head of Arabian/Indian (Doc: Rachman, 2010)

The two figurines above are the shape of the heads of foreign people that differentiated through head ornaments. With the ornamental touch, the two portray different characters. It means that skilled sculptor of the Majapahit era has the perceptual capability towards the difference between 
racial shapes and characters. This is not solely tackled through anatomical approach but also through the use of ornamental accessories presented as marker medium.

Difference in artistic quality is a common thing in each group of peoples. Only slightly handful people who have the adequate technical ability, but the rights to contribute in order to strengthen collective identity is not limited. Therefore, it is highly possible that in the Majapahit era that there are many people who attempt to create figurines, but they would have limited technical abilities. The pictures below show how individual craft forms each figurine:

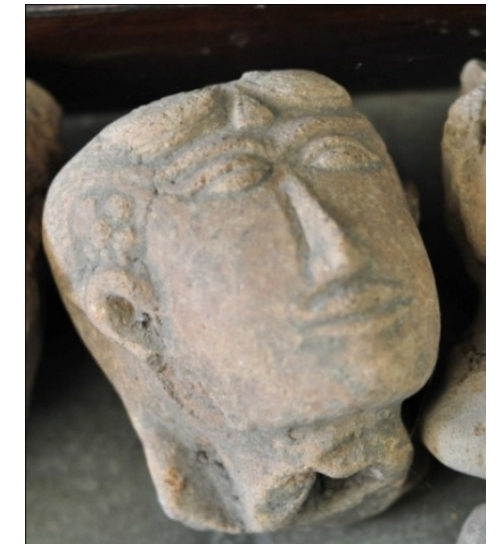

Figure 9 Female Figurine in General, Average Artistic Quality (Doc: Rachman, 2010)

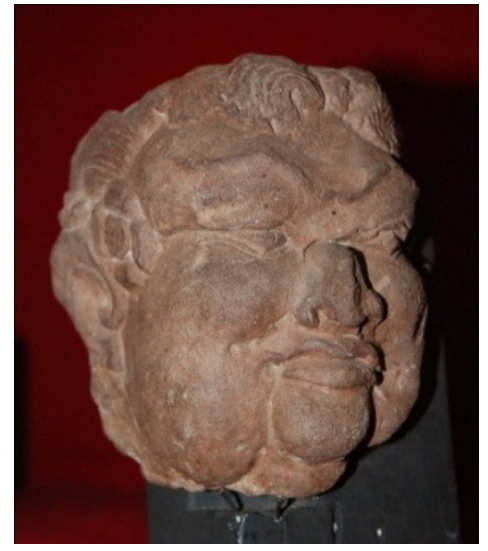

Figure 10 A Typical Majapahit Figurine, Made by a Maestro. (Doc: Rachman, 2010)

The Majapahit people are divided into two large communities. First is the community who lived within the royal court or keraton. They have their unique ornaments as the rulers and the representatives of God in Hindu. Second is the common people who lived in the outside of keraton. The normal people who had beliefs to Karesyan have much simpler ornamental compared to the royals. The influence of Hindu doctrine is very large and central to the social structure of people in general. Therefore, it is difficult to differentiate Karesyan-style figurines.

In daily life, religious rituals are given a lot of attention, while economic activities are carried out in trade activities with the outside (inter-trade activities) as well as with the inside (domestic trade activities). Religious activities are obligation that involve female, it makes female figurines are quite easy to find and discover. Other figurines that related to ritualistic aspects are displayed through the roles of priests, kings, and creatures that synonymous to gods. Their presence underlines and amplifies how the roles of gods are so respected. Hindu religious rituals at the Majapahit era, most of them begin with the process of birth, marriage to death, purification of symbolic objects, the worship of gods, and the tribute towards nature as the background in balancing between good and bad. These things are not very different from rituals of Balinese Hindu today, where they carry out rituals throughout the Saka calendar year. 


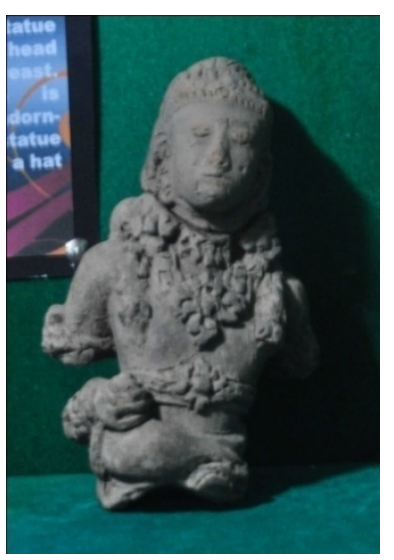

Figure 11 The Luxurious Figure of A King (Doc: Rachman, 2010)

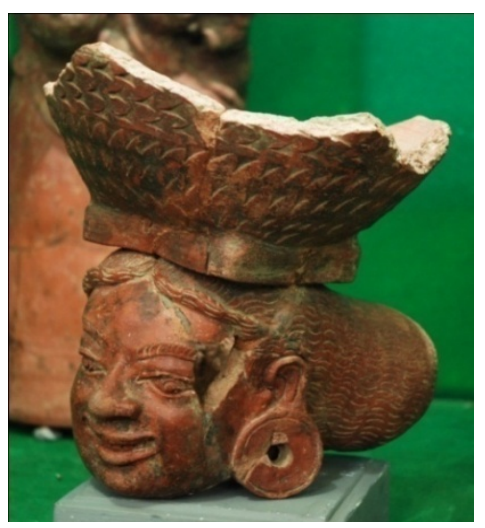

Figure 13 The Head of a Female Carrying a Ritualistic Vessel on Her Head (Doc: Rachman, 2010)

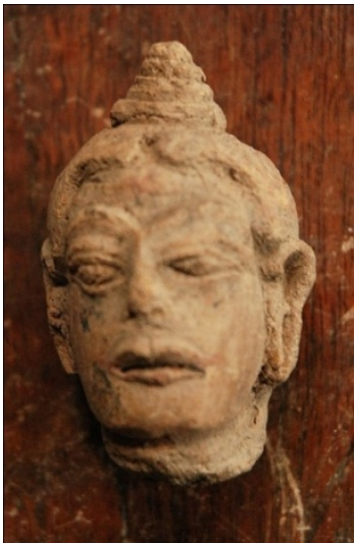

Figure 12 The Head of A Priest

(Doc: Rachman, 2010)

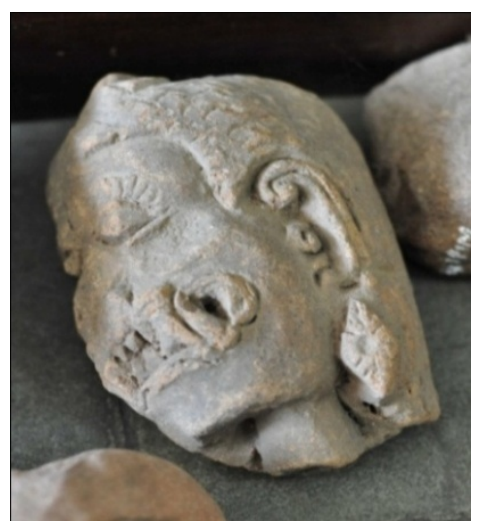

Figure 14 The Head of Hanoman, A God-like Figure

(Doc: Rachman, 2010)

In the term of occupation, Majapahit has been run like we are today. It became a common thing because they had developed a social system and social mechanism that demanded contribution from every individual to keep the wheel of social structure turning. Beside capturing about religion thing, figurines also capture about the occupation of the people. It can be identified as soldiers, musicians, farmers, and breeders. Soldiers in the governance of power was necessary and they were used as political forces against the rebel and territorial expansion. Then musicians role were handled by women, it signified a social admittance from the ruling class as when the majority of men are designated as soldiers. The occupation in the economy area, such as fishermen, farmers, and breeders could be taken up by either male or female. This can be identified from pieces of stone relief, but there are few figurines that display a female as a farm-field worker. For figurines of children and elderly, the writer still assumes that these are statements on the identification of generational strata. 


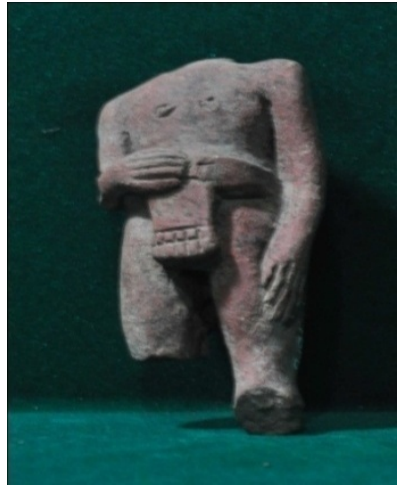

Figure 15 Fragments of a Soldier Figure (Doc: Rachman, 2010)

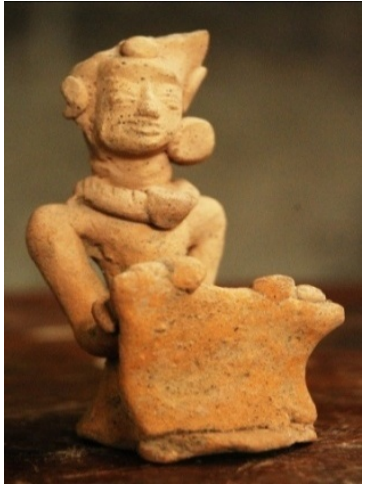

Figure 16 Female Musician (Doc: Rachman, 2010)

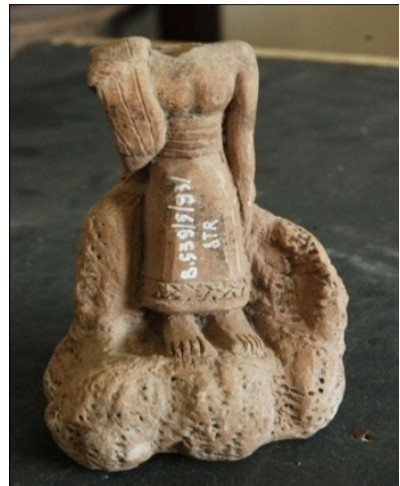

Figure 17 Fragment of Farmer (Doc: Rachman, 2010)

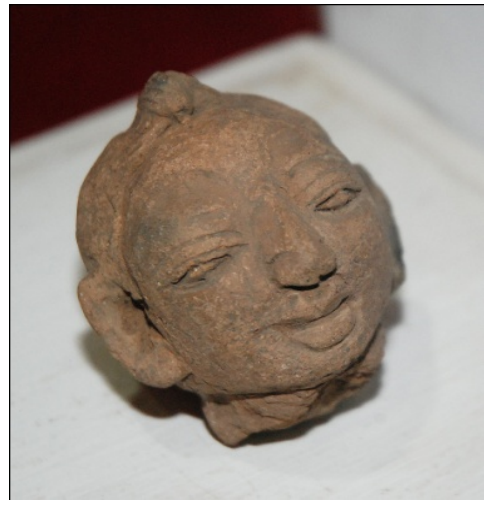

Figure 18 A Child's Head. (Doc: Rachman, 2010)

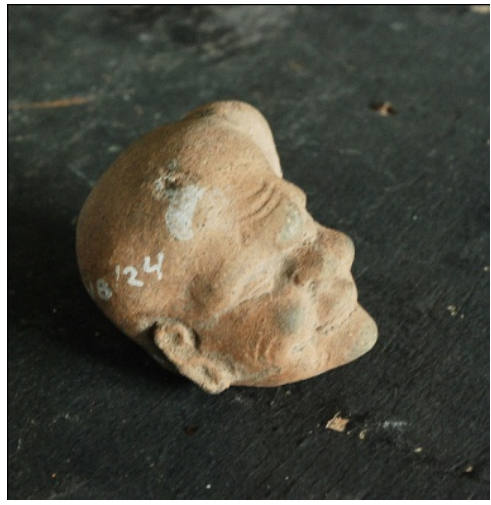

Figure 19 An Old Man's Head (Doc: Rachman, 2010)

\section{CONCLUSIONS}

Figurines as an artifact of the Majapahit era cannot be viewed simply as nothing more beyond an artistic issue. Figurines are also the result of the thoughts and actions of the people in responding to their surrounding natural environment, in addition to being a mirror of social life as guided by Hindu values. The massive number of figurines is also a portrayal of acceptance towards the involvement of every individual in the structure of everyday life. This fact is visualized in various different shapes and characters, and even the presence of foreigner figurines further underlines the breadth of social relations with regard to economic activity. In the meantime, the norms of the Hindu religion are used to understand how social dynamics is translated into 3-dimensional visual works. Within the context of relationships across humans, natural environment, and religion, we see that figurines had been viewed as one manifestation of figurative culture in Majapahit. It is equal with other manifestations such as architecture and functional device. The writer is convinced that the aesthetic of figurines plays a role as collective identity marker of the Majapahit people.

Its relevance to life today is we should consider what has been developed by Majapahit society. It is worthy to consider as a point of thought about the importance for realization of rootedness, locality, originality, and authenticity. 


\section{REFERENCES}

Hefner, R.W. (1990). Ritual and Cultural Reproduction in Non-Islamic Java. American Ethnologist, 10, 665-683. Retrieved August $9^{\text {th }}$ 2011. doi: 10. 1525/ae 1983.10.4.02a00030.

Kusen, Trihanyantoro, E., Haryono, T. (1993). Seni Majapahit. 700 Tahun Majapahit 1293 - 1993, Suatu Bunga Rampai (Ed. 2). Surabaya: Dinas Pariwisata Daerah Tingkat I Jawa Timur. hal. 237.

Nuryadi. Geomorfologi di Trowulan. Trowulan, Mojokerto, Jawa Timur. 9 November 2009. (Unpublished)

Olivelle, P. (2005). Manu's Code of Law: A Critical Edition and Translation of The ManavaDharmasastra. New York: Oxford UP.

Pigeaud, Th. G. (1962). Java in the Fourteenth Century: A Study of Cultural History The NegaraKertagama by Rakawi Prapanca of Majapahit 1365 AD. The Hague: Martinus Nijhoff.

Soemantri, H. (1997). Majapahit Terracota Art. Ceramic Society of Indonesia.

Sutikno. (1993). Kondisi Geografis Majapahit. 700 Tahun Majapahit 1293 - 1993, Suatu Bunga Rampai (Ed. 2). Surabaya: Dinas Pariwisata Daerah Tingkat I Jawa Timur.

Tanudirdjo, D.A. (1993). Pertanian Majapahit Sebagai Puncak Evolusi Budaya. 700 Tahun Majapahit 1293 - 1993, Suatu Bunga Rampai (Ed. 2). Surabaya: Dinas Pariwisata Daerah Tingkat I Jawa Timur.

Yulianto, K. (1986). Sumber Daya Pangan Pada Masyarakat Jawa Kuno. Data Arkeologi Sejarah Abad IX - X Masehi. Dalam Pertemuan Ilmiah Arkeologi, IV, Jilid 1. Jakarta: Pusat Penelitian Arkeologi Nasional, hal. 188 - 210. 